ГАЄВИЙ В.В.

\title{
ПОЗАЮРИСДИКЦЙНІ ФОРМИ ЗАХИСТУ ПРАВА ПРАЦІВНИКА НА ВІДШКОДУВАННЯ МОРАЛЬНОЇ ШКОДИ, ЗАВДАНОЇ У ТРУДОВИХ ВІДНОСИНАХ
}

Стаття присвячена вивченню позаюрисдикційної групи форм захисту права працівника на відшкодування моральної шкоди, завданої у трудових відносинах, та форм захисту, які входять до цієї групи. Особлива увага приділена аналізу самозахисту працівником власного права на відшкодування моральної шкоди, завданої у трудових відносинах, з огляду на наявні норми чинного законодавства, що регламентують таку форму захисту. 3'ясовано, що найкращою практикою захисту права працівника на відшкодування моральної шкоди та, відповідно, закріплення умов виконання обов'язку щодо такої компенсації роботодавцем буде встановлення правил та стандартів щодо цього в умовах трудового договору, посилаючись на які, працівник може пред'явити вимогу про відшкодування заподіяної моральної шкоди власнику або уповноваженому ним органу без звернення з позовом до суду чи іншого органу або не вдаватись до самозахисту. Визначено, що під поняттям самозахисту як форми захисту права працівника на компенсацію моральної шкоди, заподіяної роботодавцем у рамках трудових правовідносин, варто вважати самостійну неюрисдикційну форму захисту означеного права працівника, способами якої є самостійні правомірні дії (та/або бездіяльність) працівника, що здійснюються з метою найбільш оптимального припинення відповідної протиправної поведінки порушника (припиняється одразу після відшкодування роботодавцем моральної шкоди працівнику) без застосування примусових заходів держави, для досягнення чого працівник звертається до засобів самозахисту, якими є певні знаряддя, предмети, що можуть бути правомірно використані працівником для самостійного захисту порушеного права. Зроблено висновок, що позаюрисдикційні (неюрисдикційні) форми захисту права на відшкодування моральної шкоди як діяльність працівників або їх представників (так само сумісна діяльність працівників і роботодавців), які здійснюються ними самостійно, без звернення до відповідних юрисдикційних органів, в українському законодавстві про працю представлені такими формами захисту права працівника, як самозахист та договірна форма захисту (на підставі угоди сторін).

Ключові слова: відшкодування моральної шкоди, самозахист, моральна шкода, позаюрисдикційні форми захисту, трудові правовідносини, угода сторін, форми захисту.

The article is devoted to the study of the non-jurisdictional group of forms of protection of the employee's right to compensation for non-pecuniary damage inflicted in labour relations, and of the forms of protection that belong to this group. Particular attention is paid to the analysis of self-defense by an employee of his or her own right to compensation for non-pecuniary damage inflicted in labour relations, taking into account the existing rules of the current legislation regulating this form of protection. It has been found that the best practice to protect the employee's right to non-pecuniary damage and, accordingly, to fix the conditions of fulfilment of the obligation for such compensation by the employer, will be to set rules and standards for this in the terms of the employment contract, referring to which, make a claim for compensation for non-pecuniary damage to the owner or his authorized body without bringing an action before the court or other body, or not to resort to self-defense. It is determined that the notion of self-defense, as a

(C) ГАЄВИЙ В.В. - здобувач кафедри правознавства (Східноукраїнський національний університет імені Володимира Даля) 
form of protection of the employee's right to compensation for moral harm caused by the employer in the framework of employment relations, should be considered as an independent non-jurisdictional form of protection of the specified right of the employee, the ways of which are independent legitimate actions (and/or inaction) for the most optimal termination of the relevant unlawful conduct of the offender (terminated immediately after compensation by the employer of moral harm to the employee) without the use of compulsory ahodiv state, to achieve what the employee refers to the means of self-defense that has some tools, items that can be legally used for self-protection officer violated right. It is concluded that non-jurisdictional (non-jurisdictional) forms of protection of the right to non-pecuniary damage, as the activities of employees or their representatives (similarly: the joint activity of employees and employers), which they carry out independently, without appealing to the relevant jurisdictions, in the Ukrainian legislation the work is represented by such forms of employee rights protection as self-defense and contractual protection (based on agreement of the parties).

Key words: compensation for moral harm, self-defense, moral harm, non-jurisdictional forms of protection, labour relations, agreement of the parties, forms of protection.

Вступ. Актуальність вибраної теми очевидна з огляду на певні обставини. По-перше, за останні роки в рамках вітчизняної доктрини трудового права низка вчених досліджувала питання самозахисту трудових прав працівників. При цьому жодного разу ні в наукових, ні в науково-практичних статтях вчені та практикуючі юристи не розглядали питання самозахисту як форми захисту права працівника на відшкодування моральної шкоди, завданої в трудових відносинах. Подібна ситуація склалась із захистом зазначеного права на підставі угоди сторін. Розцінюючи такий стан розгляду цих питань у доктрині трудового права й юридичній практиці як неприпустимий, вважаємо, що комплексне дослідження сучасних неюрисдикційних форм захисту права працівника на відшкодування моральної шкоди, завданої у трудових відносинах, буде позитивно сприяти поглибленню знань щодо означених питань для вчених та практиків. По-друге, незважаючи на те, що в нашій державі досі триває реформа трудового законодавства і на порядку денному цього довготривалого процесу стоїть прийняття проекту нового кодексу про працю, український законодавець, регламентуючи позаюрисдикційні форми захисту прав працівника, неповною мірою їх деталізує, результатом чого $\epsilon$, приміром, те, що питання захисту права працівника на відшкодування моральної шкоди, завданої у трудових відносинах, фактично прямо не регламентоване проектним законодавством, що не є однозначно виправданим. Тому вважаємо, що результати цього комплексного дослідження мають бути враховані під час підготовки проекту ТК України як такі, що зможуть поліпшити стан захищеності права працівника на відшкодування моральної шкоди, завданої у трудових відносинах.

Сприятиме досягненню поставленої мети в процесі наукового пошуку звернення до суміжних галузей права, аналіз точок зору спеціалістів, науковців з цього питання (С.В. Горбачьова, Є.Б. Козакова, М.В. Лушнікова, О.М. Лушніков, Г.О. Свердлик, Е.Л. Страунінг, В.Д. Чернадчук, А.Л. Юріна), вивчення положень нормативно-правових актів.

Постановка завдання. Метою статті є дослідження позаюрисдикційних (неюрисдикційних) форм захисту права працівника на відшкодування моральної шкоди, заподіяної в трудових правовідносинах за законодавством України.

Результати дослідження. Відмінність права на захист від інших прав такого типу полягає в тому, що це право має самостійне значення в механізмі правового регулювання і вищому ступені, фіксує свободу правомірної поведінки суб'єктів права. Отже, право на відшкодування моральної шкоди $\epsilon$ важливою гарантією захисту прав і свобод громадян, що визначається нормами трудового законодавства, яке регулює процедуру чи процес розгляду індивідуальних трудових спорів (такі спори розглядаються, якщо право на ії відшкодування безпосередньо передбачене нормами Конституції України або випливає з ії̈ положень, а також у випадках, передбачених ЦК України та іншим законодавством).

При цьому захист такого права може відбуватись шляхом звернення працівника, який зазнав моральної шкоди, до однієї з груп форм захисту: юрисдикційної, квазіюрисдикційної та позаюрисдикційної. Серед зазначених груп форм захисту найбільш оптимальним у правовому суспільстві є форми захисту, що входять до позаюрисдикційної групи, оскільки звернення працівника до таких форм захисту не обмежено складними процедурами $\mathrm{i}$, як правило, певними бар'єрами захисту, як-то строки, доказування тощо. 
Варто зазначити, що в доктрині трудового права під поняттям «неюрисдикційні форми захисту» розуміються дії працівників або їх представників із захисту прав та інтересів, які здійснюються ними самостійно, без звернення до відповідних юрисдикційних органів. Однак у сучасній науці трудового права також і зустрічаються визначення, коли до неюрисдикційних форм захисту зараховують також і квазіюрисдикційні форми. Зокрема, А.Л. Юріна зазначає, що неюрисдикційна форма захисту охоплює дії громадян й організацій щодо захисту цивільних прав та охоронюваних законом інтересів, що здійснюються ними самостійно, без звернення за допомогою до державних та інших уповноважених органів [1, с. 105].

До неюрисдикційних форм захисту права працівника на відшкодування моральної шкоди, завданої у трудових відносинах роботодавцем, варто зараховувати наведені нижче форми.

1. Договірна форма захисту права працівника на відшкодування моральної шкоди в рамках трудового права (на підставі угоди сторін). У тих випадках, коли працівник не бажає звертатись до юрисдикційних чи квазіюрисдикційних форм захисту свого права на відшкодування шкоди, а роботодавець погоджується відшкодувати таку шкоду після врегулювання розміру такої шкоди без звернення до суду, профспілки тощо (це не виключає можливості залучення фахівців психіатрів, терапевтів, дерматологів, сексопатологів тощо), то працівник та роботодавець можуть врегулювати спірне питання в досудовому порядку, без залучення державних чи громадських органів, не створюючи відповідні примирні-третейські органи. Проте задля наповнення змістом таких дій сторін та отримання відповідних юридичних гарантій такий працівник та роботодавець мають укласти угоду про вирішення такого спору за угодою сторін. Власне, такі дії не забороняє ані трудове, ані цивільне законодавство. Зокрема, відсутні застереження щодо такого і в ст. 23 ЦК України, в якій не встановлюються обмеження щодо визначення умов відшкодування моральної шкоди в договірному порядку.

Найкращою ж практикою захисту права працівника на відшкодування моральної шкоди та, відповідно, закріплення умов виконання обов'язку щодо такої компенсації роботодавцем буде встановлення правил та стандартів щодо цього в умовах трудового договору, посилаючись на які, працівник може пред'явити вимогу про відшкодування заподіяної моральної шкоди власнику або уповноваженому ним органу без звернення з позовом до суду чи іншого органу або не вдаватись до самозахисту.

Варто погодитись із В.Д. Чернадчук, який вважає, що метою такої угоди є позасудове врегулювання індивідуального трудового спору та припинення зобов'язань із відшкодування працівникові моральної шкоди в судовому порядку [2, с. 11]. Тобто така форма захисту є найбільш оптимальним інструментом відшкодування моральної шкоди, хоча досить спірною є оптимальність такої форми захисту як варіанту захисту права працівника на відшкодування моральної шкоди, оскільки закономірно, що працівник буде весь час завищувати розмір моральної шкоди, яку треба відшкодувати, а роботодавець - занижувати. Тому у використанні цієї форми захисту все залежить від суб' єктивних факторів, як-то: чесність і об'єктивність працівника та роботодавця, їхня правова та професійна обізнаність тощо.

Видається можливим внесення таких правил та стандартів як змін до трудового договору (лише тоді, коли такі не передбачені в чинному трудовому договорі; зміни до наявних умов відшкодування моральної шкоди в чинному трудовому договорі мають бути заборонені) в передбаченому законом порядку, або укладання з працівником (за згодою працівника) таких правил і стандартів у формі додаткового документа, який приєднується до чинного трудового договору і вважається його частиною (якщо такі правила й стандарти не передбачені в чинному трудовому договорі; якщо наявні правила й стандарти вважаються неповними, їх можна деталізувати в окремому документі за описаною процедурою, проте якщо з такою деталізацією погоджується працівник).

2. Самозахист. У доктрині трудового права розуміння поняття «самозахист працівником своїх трудових прав» $€$ неоднаковим, це поняття, як правило, розглядають як форму захисту трудових прав, спосіб забезпечення реалізації трудових прав, засіб захисту трудових прав, і форма, і засіб захисту трудових прав.

Поряд із тим, аналізуючи поняття «спосіб» і «форма» захисту і зіставляючи різні законодавчі положення про самозахист, можна погодитись з Є.Б. Козаковою, яка вважає, що самозахист - це форма захисту з притаманними їй способами [3, с. 10], якими вважаються конкретні дії (або бездіяльності) чи система дій (або бездіяльності), здійснюваних людиною для відображенні, припинення правопорушення або відновлення становища, яке існувало до правопорушення [4, с. 8]. 
Поняття «самозахист» розуміється як позаюрисдикційна форма захисту трудових прав працівника, яка складається, зокрема, із сукупності дозволених, визнаних або не заборонених державою дій самої людини за обгрунтованим і законним попередженням, припиненням і відображенням порушень, а також відновлення порушених (оспорюваних) суб'єктивних прав, свобод і законних інтересів без звернення за допомогою до компетентних органів [4, с. 7].

При цьому самозахист є можливим за наявності в сукупності певних умов $[3$, с. 7,15$]$ : 1) є порушення права або спроба його порушення (в аспекті нашого питання - спроби уникнення роботодавцем відповідальності за моральну шкоду, завдану працівнику, чи відкрите ігнорування такого обов'язку); 2) виникає необхідність припинити (попередити) порушення (приміром, працівник відмовляється від виконання своїх трудових функцій на період допоки моральна шкода, якої йому завдав роботодавець і не бажає ії відшкодовувати, не буде відшкодована, тому що працівник потребує компенсаційних коштів, які він використає, приміром, на фахову психологічну допомогу лікаря); 3) варто застосувати заходи, що відповідають характеру і змісту правопорушення (не зовсім буде правомірним самозахист коли, приміром, працівник, якому було завдано роботодавцем моральну шкоду, буде розкривати «секрет фірми» роботодавця, поширювати відомості фінансової звітності роботодавця тощо; не буде вважатись самозахистом права на відшкодування моральної шкоди працівником і використання способів самозахисту, використання яких завдає роботодавцю більшої шкоди, аніж розмір завданої шкоди працівнику, якщо працівнику завдано моральну шкоду в умовному розмірі 10000 грн., то невихід на роботу працівника-потерпілого протягом місяця, що завдає роботодавцю шкоди більше 10000 грн., теоретично вважається неприйнятним, а такий «самозахист» розцінюється як неправомірний самозахист, тобто самоуправство).

Разом із тим варто зауважити, що така форма захисту трудових прав характеризується певними ознаками, основними 3 яких є такі [5, с. 157-158; 6, с. 19]: 1) такий захист має правоохоронний характер (підставою застосування такого захисту є правопорушення, інакше такі дії можуть бути розцінені як самоуправство); 2) самозахист має характер односторонніх дій (у разі активного самозахисту) або бездіяльності в разі неактивного самозахисту - невихід на роботу, невиконання на робочому місці робочих функцій тощо) суб'єкта трудових правовідносин; 3) самозахист як форма захисту дає змогу застосовувати способи захисту (їх застосування $\epsilon$ правом особи і відбувається в позаюрисдикційному порядку).

3 цього виходить, що значення права на самозахист для людини та для суспільства, виключно помітне, зокрема тому, що інтереси особи поважаються, якщо сама ця особа здатна і за звичаєм схильна захищати їх. Інакше бездіяльність заінтересованої особи призводить до поширення правопорушень та безкарності, що, своєю чергою, знижує загальний рівень особистої безпеки людини. Чим активніше людина буде здійснювати діяльність із самостійного захисту своїх прав, свобод і законних інтересів, тим менше буде приводів до порушень іiі прав [4, с. 4]. Однак $\epsilon$ випадки, коли трудове право працівника може порушитись, незважаючи на активність поведінки такого працівника. Тим більше працівник не зобов'язаний постійно піклуватись і контролювати роботодавця з метою унеможливлення порушення власних трудових та інших права й законних інтересів. Увага працівника має бути зосереджена на виконанні власних трудових обов'язків, а про непорушність його трудових прав має турбуватись як безпосередньо роботодавець, так i профспілка (якщо така створена на підприємстві і такий працівник є членом цього об'єднання).

Таким чином, під поняттям самозахисту як форми захисту права працівника на компенсацію моральної шкоди, заподіяної роботодавцем у рамках трудових правовідносин, варто розуміти самостійну неюрисдикційну форму захисту означеного права працівника, способами якої $\epsilon$ самостійні правомірні дії (та/або бездіяльність) працівника, що здійснюються з метою найбільш оптимального припинення відповідної протиправної поведінки порушника (припиняється одразу після відшкодування роботодавцем моральної шкоди працівнику) без застосування примусових заходів держави, для досягнення чого працівник звертається до засобів самозахисту, якими $\epsilon$ певні знаряддя, предмети, що можуть бути правомірно використані працівником для самостійного захисту порушеного права.

Висновки. Отже, підбиваючи підсумки вищевикладеного, варто зауважити, що позаюрисдикційні (неюрисдикційні) форми захисту права на відшкодування моральної шкоди як діяльність працівників або їх представників (так само сумісна діяльність працівників і роботодавців), які здійснюються ними самостійно, без звернення до відповідних юрисдикційних органів, в українському законодавстві про працю представлені такими формами захисту права працівника, як самозахист та договірна форма захисту (на підставі угоди сторін). 


\section{Список використаних джерел:}

1. Юріна А.Л. Співвідношення понять форми, способу, міри і порядку захисту в науці цивільного права. Становлення та розвиток правової держави: проблеми теорії та практики. 2009. C. 104-108.

2. Чернадчук В.Д. Відшкодування моральної шкоди при порушенні трудових прав : автореф. дис. ... к.ю.н. : 12.00.05 «Трудове право; право соціального забезпечення». Київ, 2001. 14 с.

3. Казакова Е.Б. Самозащита как юридическое средство: Проблемы теории и практики: автореф. дис. ... к.ю.н. : 12.00 .01 «Теория и история права и государства; история учений о праве и государстве». Тамбов, 2006. 24 с.

4. Горбачева С.В. Самозащита прав по российскому законодательству : автореф. дис. ... к.ю.н.: 12.00.01 «Теория и история права и государства; история учений о праве и государстве». Нижний Новгород, 2005. 21 с.

5. Лушникова М.В., Лушников А.М. Курс трудового права: В 2 т. Т. 1: Трудовое право в системе прав человека. Индивидуальное трудовое право : Учебник. Москва : Проспект, 2004. 608 с.

6. Свердлык Г.А., Страунинг Э.Л. Понятие и юридическая природа самозащиты гражданских прав. Государство и право. 1998. № 5. С. 17-19.

УДК $342 ; 349.3$

DOI https://doi.org/10.32844/2618-1258.2019.6.11

ДЕНЕГА О.П.

\section{ПРОБЛЕМИ ПРАВОВОГО РЕГУЛЮВАННЯ ДІЯЛЬНОСТІ ДЕРЖАВИ ЯК СУБ'СКТА ПРАВА СОЦІАЛЬНОГО ЗАБЕЗПЕЧЕННЯ В УМОВАХ ЄВРОІНТЕГРАЦІЇ УКРАЇНИ}

У статті проаналізовано специфіку проблемних питань щодо правового регулювання діяльності держави як суб'єкта права соціального забезпечення в умовах євроінтеграції України. Виявлено перелік таких проблем, визначено їх зміст і деталізовано характеристику кожного з них. Наведено аргументовані авторські пропозиції щодо шляхів їх вирішення. 3'ясовано, що правове регулювання діяльності держави як суб'єкта права соціального забезпечення в умовах євроінтеграції України здійснюється великою кількістю нормативно-правових актів, що збільшує ризики виникнення неузгодженостей між ними. На цьому етапі у вказаній сфері налічується більше сотні законів України та декілька сотень підзаконних нормативно-правових актів. Одним із можливих шляхів для вирішення цієї проблеми може стати вже запропоноване нами прийняття Соціального кодексу України. Наголошено, що правове регулювання діяльності держави як суб'єкта права соціального забезпечення в умовах євроінтеграції України полягає у тому, що воно здійснюється за законодавством, яке не включає ряд важливих європейських стандартів. Визначено, що правове регулювання діяльності України як суб'єкта права соціального забезпечення в умовах євроінтеграції здійснюється на засадах, відмінних від правового регулювання діяльності європейських держав як суб'єктів права соціального забезпечення. Зроблено висновок, що в основі кожної держави як суб'єкта права соціального забезпечення в умовах євроінтеграції України перебуває недосконалість чинного законодавства: воно $є$ застарілим, перенасиченим нормативно-правовими актами, неадаптованим до європейських стандартів, суттєво відрізняється від соціального законодавства європейських держав. Нами встановлено, що найбільш оптимальним шляхом для вирішення існуючих проблем $\epsilon$ систематизація соціального законодавства України. Також запропоновано рати- 